\title{
Antes da chuva: metamorfoses do círculo
}

\author{
Olgária Chain Féres Matos* \\ Universidade de São Paulo, Faculdade de Filosofia Letras e Ciências Humanas. Departamento de Filosofia. São Paulo, SP, Brasil
}

\begin{abstract}
Resumo: Este ensaio procura mostrar de que maneira a modernidade tecnológica produz em permanência comportamentos arcaicos, preservados no interior da civilização que se pretende lógica e científica. Da pseudoformação escolar aos particularismos políticos, do fim do espaço público às legislações submetidas a lobbies, passa-se da ideia de polis - a cidade como destino comum de uma coletividade que partilha os mesmos valores - à thyase - organização de grupos na forma de seitas - religiosas ou políticas. Mostra-se, assim, o modo de produção do mal-estar e da violência no mundo contemporâneo, só podendo ser superados rompendo-se com os particularismos ressentidos e com a política que opõe amigo e inimigo. Neste sentido, assim como o futuro é contingente, o passado também o é, podendo ser reaberto em suas esperanças de paz e felicidade não cumpridas e que podem fazer advir o presente.
\end{abstract}

Palavras-chave: fundamentalismos, tecnologia, violência, inimigo, parti pris, não-violência, identidades, aceleração do tempo, olhar.

No apogeu da civilização que se autoestima lógica, que venceu os obscurantismos na ciência, na religião e na política pela explicação racional do mundo, em que "nada é sem razão" e o homem é o agente do progresso social, o filme Antes da Chuva, de Manchevski, trata das regressões da sociedade: fragmentação política, retorno de fundamentalismos religiosos e ódios étnicos. Construindo um tríptico no âmbito dos Bálcãs e da guerra de religião entre cristãos ortodoxos e muçulmanos da Macedônia, sucedem-se três episódios: "palavras", "rostos" e "fotografias". Como o retábulo que é fechado e reaberto, o tempo dos acontecimentos pode retornar e ser também outro, tomando um rumo inédito, pois "o tempo não pára e o círculo não é redondo". Porque o conflito se apresenta no plano dos fundamentalismos religiosos - já que os grupos armados são muçulmanos e cristãos - eles diferem do sentido espiritual que a contemplação e a fé supõem. Para romper com o círculo vicioso da violência, Manchevski propõe um círculo que não é redondo, a volta não corresponde à repetição, o círculo não indica mais fechamento e conclusão, a violência não tem a última palavra.

Entre os séculos XVI e XVII europeus, com o desenvolvimento da ciência e da técnica no sentido da dominação da natureza e do empreendimento da Conquista, com a ocupação do continente americano, tem fim o cosmos grego e a natura loquax em que se manifestava a lux divina. Colocando-se no lugar de Deus, a razão iluminista exilou o divino do mundo dos homens, desencantou o mundo e confinou o fenômeno religioso na dimensão privada, despojando-o de suas prerrogativas de experiência afetiva e de laço social, uma vez que - à luz da razão - a religião encontra-se no plano do irracional. Darwin, Nietzsche, Marx e Freud são os neorrealistas e desevangelizadores, o primeiro para quem o homem não apresenta mais qualquer dignidade própria no cosmos, não é criatura divina, apenas um primata superior; Nietzsche descobre a ideia de Deus e os valores morais como invenções humanas e sistema de luta entre fortes e fracos; Marx reconhece nela a alienação a serviço da exploração e, para Freud, a religião é uma superstição pública, na mesma medida em que a superstição é uma religião privada. Mas a "superação" da religião como explicação do universo natural e humano foi um empreendimento ambíguo. Desanti, em seu livro Introdução à História da Filosofia, observa que o divórcio entre ciência e religião, a mundanização, foi um processo dúbio, pois ela realizou

um uso "sagrado" da ciência. Galileu "funda" a verdade da física sobre o conceito de entendimento infinito de um deus matemático. Uso sagrado da ciência, visto que, em suma, a essência da religião subsiste em sua abstração e que os conceitos científicos vêm, por assim dizer, dar-lhe conteúdo e conferir-lhe autoridade própria. Mas no mesmo ato e de maneira contraditória esse uso sagrado da ciência é um uso profano da religião. (Desanti, 1956, p. 34)

A guerra entre sérvios, croatas, bósnios e albaneses reconduz, para além da exclusão das religiões do espaço público, à questão das religiões no horizonte das reordenações do capitalismo contemporâneo. Em sua obra $L a$ Revanche de Dieu, Gilles Kepel (2003) refere-se às três grandes "religiões do Livro" - o judaísmo, o cristianismo e islamismo - e ao que lhes foi reservado no horizonte do "desencantamento do mundo" - as religiões perdem espaço na vida pública e na organização da vida social, consideradas, desde o Iluminismo, como obscurantismo, ideologia e ilusão. Na história do pensamento costuma-se datar a propaganda da "não-fé" após a morte de Hegel, quando os descendentes filosóficos de uma "esquerda metafísica" deram-se por missão divulgar no mundo burguês o "mais alto 
mistério da filosofia", o arcano, antes restrito ao hermetismo dos saberes ocultos, segundo os quais não existe Deus, nem deuses, e, em consequência, o mundo verdadeiro só poderia ser o mundo real que habitamos. Dele tem-se um conhecimento insuficiente, uma vez que nosso olhar fora educado para a transcendência. Durante séculos o povo e os cultivados ingênuos acreditaram que o mundo verdadeiro se encontrava em um além superior, quando chegou a hora de o real reconquistar a verdade.

No novo paradigma, a realidade do real, liberada das alturas ilusórias, será deduzida do corpo, como em Darwin, do dinheiro, em Marx, da vontade de poder, em Nietzsche, e do medo da morte, em Freud. Antes de Hegel, durante a Revolução Francesa, o pragmatismo burguês se espalhou pela Europa, segundo o esoterismo naturalista do marquês de Sade, para quem a verdade última sobre a matéria capaz de prazer revela-se exclusivamente àqueles raros espíritos livres, puros media da natureza a partir do momento em que professam sua fé no crime considerado a técnica suprema da felicidade. Mesmo afastada de Sade, a modernidade subsequente manteve a atitude antropológica fundamental de auxiliar o homem, criatura da carência e da falta, a encontrar satisfação de seus desejos neste mundo.

Se o retorno dos fundamentalismos religiosos evoca a cultura capitalista do "desencantamento psíquico e da cultura", no plano da economia eles ocupam o lugar da luta pela hegemonia de projetos minoritários, como o sunita, o copta, o maronita, o palestino e o sionista, e disso resulta a luta entre cristãos e muçulmanos. Na contradição entre chefias religiosas e Estado laico reconhece-se também a passagem do capitalismo industrial - baseado na produção, no trabalho organizado, nas ideias de qualidade e durabilidade dos produtos e em estoques - ao capitalismo pós-industrial - em que predominam a fragmentação e a dispersão da produção econômica, a acumulação "flexível" do capital incidindo diretamente sobre os trabalhadores que perdem seus referenciais de identidade, de organização e de luta, com a rotatividade da mão de obra, o poder do capital financeiro, o advento dos produtos descartáveis, obsolescência das qualificações e habilidades, decorrentes das novas tecnologias, causando-se exclusão social, miséria econômica e moral. Que se pense aqui no desaparecimento dos laços pessoais na produção (fim da solidariedade, da afetividade e da convivência nas organizações dos trabalhadores, no empreendimento de melhoria das condições de trabalho e em sua função de mediadoras nas relações de poder na esfera da produção). Também as novas tecnologias - e a automação de uma maneira geral - não liberaram os homens de tarefas dolorosas, mas do conteúdo e do sentido do trabalho - circunstância a que Benjamin (2006) se refere nas Passagens, aludindo a Sísifo e às Danaides. Sísifo, condenado a carregar o rochedo até o alto do precipício que rola novamente para o ponto de partida, recomeça a mesma tarefa indefinidamente. Também as Danaides devem encher, por condenação divina, tonéis com a água do mar, mas esses recipientes, aos quais falta o fundo, esvaziam-se e elas devem recomeçar do zero a absurda tarefa. Assim como o trabalho alienado "arruína o corpo e martiriza o espírito", o tempo é sem experiência, o que o converte em um presente cristalizado do qual se ausenta o futuro. Todos os vínculos que supõem o longo prazo - como juramento e promessas, relações de pais e filhos, casamento e amizade - desaparecem, tendendo-se, progressivamente, à incivilidade. A temporalidade imobilizada, por assim dizer, no presente, é a da aceleração do tempo e de sua contração, incidindo na formação educacional. Gilles Kepel (2003) indica seu impacto nos movimentos religiosos. Entre os anos 1960 e 1970 - diante da dificuldade de expressão política - ressurge uma militância religiosa que, do lado cristão, encontra-se na nova evangelização da América, a guerra do Golfo, as guerras do Afeganistão, do Iraque e a ameaça ao Irã ("salvar a América"); do lado judaico, há a afirmação bíblica do Estado de Israel, tratado como "Terra de Israel"; entre muçulmanos não se procura modernizar o Islã, mas "islamizar a modernidade". Essa militância não procede do mundo rural tradicionalista, tampouco das classes populares, mas de intelectuais obscuros, sem reconhecimento público, formados em disciplinas técnicas e suas noções de eficácia e de produtividade. Abdelwahab Meddeb (2004) chama a atenção, por sua vez, para as características da educação e da cultura que o capitalismo contemporâneo produz: a difusão de uma educação medíocre para a grande massa - a pseudoformação - o pensamento por clichês e estereótipos, que inviabilizam o pensamento autônomo, este, mais resistente a manipulações, é mais atento a escolhas e ações favoráveis à emancipação e a entendimentos que levam à paz. Em outras palavras, a semiformação produz a cultura do ressentimento:

O ressentimento produz valores, imagens identitárias e ideias cívicas que visam inverter [o lugar] daqueles que dominam, considerados propriedade do grupo que se vê como despossuído ou reivindicador. ... O discurso do ressentimento funciona como o "sempre ter razão", inacessível a qualquer objeção e refutação. O ressentimento encontra-se nas ideologias nacionalistas, nos fundamentalismos, nos particularismos comunitários . . . e consiste numa espécie de privatização da moral. (Angelot, 1998, pp. 111-112)

Considere-se, ainda, a compressão e aceleração do tempo que determinaram a perda brusca de tradições, crenças, modos de vida e valores, sob o tempo hegemônico no Ocidente, o do capital financeiro, que destrói pertencimentos criando paranoias étnicas e religiosas em que a crise de identidade procura uma compensação no conflito, rompendo laços sociais entre antigos conhecidos de tal forma que todos podem se tornar inimigos e assassinos de todos. Com a fragmentação política da ex-Iugoslávia e o fim do antigo "Estado nacional" ditatorial - ligado às práticas estalinistas de expurgos partidários, perseguições políticas, encarceramento de oposições e convenções partidárias sempre votadas por unanimidade, a população e também 
a burocracia de Estado dominadas pelo terror e pelo medo - o esfacelamento político dos anos 1990 resultou em que, nos mostra o filme, muçulmanos albaneses civis armados perseguissem cristãos ortodoxos macedônios. Populações inteiras foram expostas e submetidas a um profundo estresse com respeito à sua inscrição no mundo globalizado, para o qual não foram preparadas nem psiquicamente, tampouco institucionalmente. Daí a busca de um ponto de apoio em antigas e "outras" fronteiras. Comunidades tornadas histéricas transformam fantasmas passados em arquétipos - a perseguição de cristãos, há cinco séculos, pelo império turco - com o retorno a fundamentalismos religiosos e ódios étnicos. Franco Berardi (1994) observa que o desmoronamento dos sistemas sócio-autoritários do leste europeu resultou da difusão das tecnologias comunicacionais, primeiramente a televisão e a telemática que facultaram o ingresso de imagens, mitologias, expectativas psicológicas e necessidades sociais para além de qualquer fronteira ou separação nacional, cultural e política. Com a queda do muro de Berlim, não se liberaram energias sociais, mas o mercado de bens de consumo, o que adquiriu as características de uma onda de pânico:

O desmoronamento do sistema de seguridade social funcionou como um verdadeiro terremoto psíquico a que se seguiu uma agressividade nacionalista, étnica, militarista. . . . O modo de desterritorialização está se revelando ingovernável segundo o modelo da democracia formal e da economia de mercado e provocou um contramovimento de reterritorialização paranoica e, frequentemente, desesperada. (Berardi, 1994, pp. 141-142)

No paradoxo de uma crescente presença de informações na esfera pública e de difusão de comportamentos gregários - integristas, violências tribais e economias mafiosas - prevalecem dogmas de pertencimentos, referência a origens e raízes, no apagamento de perspectivas humanas universalizáveis, com a queda na guerra de todos contra todos. Ficção e preconceito, o fantasma de pertencimento é uma fabulação cultural e histórica,

uma projeção retroativa da necessidade de identidade. Mas tal ficção - que se estabiliza na forma do racismo, do integralismo religioso e do populismo - funciona como fator agregativo e como critério de decisão. Em situações de indecisão escolho como meu grupo de pertencimento (sem me dar conta, naturalmente, do fato que este é meu grupo de pertencimento somente porque escolhi conformar-me a ele). (Berardi, 1994, p. 149)

Na fita, comunidades que até há pouco viviam lado a lado, em relações de proximidade, parentesco e vizinhança, dividem-se em amigos e inimigos, macedônios cristãos ortodoxos contra albaneses muçulmanos, de tal forma que o amor (do protagonista Alexander e de Anna) fica interditado.
Poder-se-ia pensar aqui nas análises de Reich acerca da peste emocional que impede abrir-se ao outro e a ele entregar-se, inviabilizando viver a sociedade como horizonte do desejo, em particular se se pensa na sociedade como um laço social agregativo, a philia, um laço afetivo e libidinal:

A sociedade se transforma em horizonte do medo, da insegurança e da angústia, o outro vem a ser o objeto de investimentos agressivos. . . O medo da contaminação étnica, cultural, religiosa, acrescido do temor da concorrência econômica, fez eclodir uma verdadeira obsessão de pureza étnica, de proteção da identidade, de separação social e territorial. (Berardi, 1994, pp. 154-155)

Pode-se reconhecer nas guerras contemporâneas crises de mudança nas formas do mundo. O Estado - de mantenedor a longo prazo da vida de todos os cidadãos na linha do tempo - converte-se em gestor da economia; na transformação da economia de mercado em sociedade de mercado, todas as determinações da vida passam a ser as do valor econômico. Não há mais normas estáveis; direitos sociais, civis e políticos perdem eficácia e aplicabilidade, tendendo a se dissolver, pois eles constituíam os elementos críticos do capitalismo liberal, que, como salário indireto, protegiam os indivíduos da força de acumulação do Capital. Como barreira a seu acréscimo anômalo, os direitos vão sendo progressivamente abolidos. Que se pense no prolongamento e intensificação da jornada de trabalho, na flexibilização dos direitos trabalhistas, na extensão do tempo de trabalho ao longo da vida.

Com o advento dos satélites e da TV a cabo, o estilo de vida ocidental, sobretudo o norte-americano, de consumo e publicidade, atingiu populações forçadas ao racionamento e às filas intermináveis para adquirir alimentos e bens de uso, populações que se viram confrontadas à questão da liberdade. Com o fim do estalinismo a que deveria seguir a liberdade, os particularismos políticos revelaram que a luta pela liberdade foi sobretudo luta pela liberdade de consumo e não luta pela liberdade social e política, pois instituiu-se uma internacional de consumidores. A mídia hegemônica no Ocidente, por intermédio da qual há a identificação de liberdade e consumo, felicidade e posse de bens materiais, desmontou o leste europeu.

A população retratada no filme, a de dois milhões de indivíduos, compreende $50 \%$ de ortodoxos eslavos que se consideram macedônios, $30 \%$ de albaneses muçulmanos, $20 \%$ de sérvios, gregos, ciganos, búlgaros e turcos, com pluralidades linguísticas e religiosas. Na ausência de um espaço político, sem laços efetivos de união e diálogo, resta-lhes a disputa por uma suposta identidade (religiosa, étnica, linguística), embora nas aldeias todas estas línguas, etnias e religiões estejam misturadas em um espaço comum, segregados, agora, pela guerra, como se vê no confinamento dos bairros cristãos e o dos muçulmanos no filme. Apesar da mestiçagem secular, sobrepõem-se tendências separatistas entre macedônios e albaneses, numa 
tentativa imaginária de união com os albaneses de Kosovo. As mortes a que assistimos são causadas por albaneses assassinando albaneses e macedônios ortodoxos matando-se entre si. Repetindo em um mundo prosaico as tragédias clássicas - as do séc. V a. C. - em que a violência ocorre no interior de uma mesma família (como em Antígona - em que os irmãos se matam reciprocamente, Édipo que mata o pai) - esse ciclo de violência, preconceito, ódio e medo retorna, reavivando séculos de conflitos do passado. À tendência à fragmentação política segue uma outra, a do desaparecimento da lei pan-inclusiva que até há pouco regeu o Estado Moderno e a experiência do espaço público, onde diferenças de raça, religião, poder econômico ou prestígio se anulavam pelo pertencimento a um espaço compartilhando os mesmos valores e as mesmas leis, um mundo comum a todos e acessível a todos. As políticas compensatórias, como as cotas, manifestam-se como a forma de solidariedade própria às práticas neoliberais privatizantes. A esta flexibilização da Lei universalizadora corresponde à “ insegurança jurídica” do estado de exceção que, nas palavras de Benjamin, é a regra do mundo contemporâneo. A fita nos mostra de que maneira o homem se encontra na condição do homo sacer, aquele que pode ser morto a qualquer momento e esse assassinato é impunível. Com respeito a que Giorgio Agamben escreve:

A exceção é uma espécie de exclusão, é um caso especial que é excluído da norma geral. Mas o que caracteriza propriamente a exceção é que o excluído não fica por isso absolutamente privado de conexão com a norma; ao contrário, mantém-se em relação com ela na forma de sua suspensão. A norma aplica-se à exceção desaplicando-se, retirandose dela. O estado de exceção não é, pois, o caos que precede a ordem, mas a situação que resulta de sua supressão. Neste sentido a exceção é, verdadeiramente, segundo a etimologia, "puxada para fora" (ex-capere) e não simplesmente excluída. . . . Não é a exceção que se subtrai à regra, mas a regra que, suspendendo-se, dá lugar à exceção e, apenas deste modo, constitui-se como regra, mantendo-se em relação com aquela. (Agamben, 2002, pp. 30-31)

O homo sacer se inscreve na política entendida na oposição amigo-inimigo, isto é, na lógica do ressentimento, segundo o par modelo-rival, cujo lugar é indefinido, nem aquém nem além da lei e do direito, um não-lugar que faz dele alguém que pode ser assassinado e o crime é impunível, dada sua situação extra-jurídica. O homo sacer é um morto-vivo, biologicamente vivo, mas virtualmente morto. Desaparece, assim, a fronteira entre fato e direito, entre as formas de vida pré-políticas, não regidas pelas leis, e as leis que constituem a vida na polis, não sendo mais possível diferenciar o que procede dos costumes e o que é instituição política. Assim, a suspensão das leis positivas, em sua inaplicabilidade e na ausência do Estado, resulta na condição de absoluta desproteção do indivíduo. As formas modernas da sociabilidade fazem ressurgir as cidades-estados, com habitantes enclausurados em seus espaços privados, sob o domínio da insegurança social, como ocorre nas guerras modernas, nos terrorismos e nos ataques da criminalidade.

No filme, as ideias de sociedade e de vida em comum desconhecem as formas elementares da comunidade política daqueles que agem em conjunto para a vida boa e feliz, o contrário da cidade perfeita, aquela que assegura o máximo de sobrevivência, segurança, justiça e liberdade a cada um de seus membros. A atual modalidade da vida social pouco vale para o enraizamento, produzindo o sentimento de se ser estrangeiro no mundo, sem a compensação do cosmopolitismo, da hospitalidade e do acolhimento, formas que tendem à unidade da multiplicidade dos indivíduos que compõem uma coletividade. A fita mostra a proliferação de particularismos, nacionalismos e exclusão do próximo segundo o "narcisismo das pequenas diferenças", a única forma de preservar uma identidade que vacila é diferenciar-se do que, por sua semelhança, ameaça com a indiferenciação, a volta ao amorfo e a dissolução do Eu. Horkheimer e Adorno (1985) referem-se ao fenômeno da mimese, aqui atuante:

Só a mímese se torna semelhante ao mundo ambiente, a falsa projeção torna o mundo ambiente semelhante a ela. Se o exterior se torna para a primeira o modelo ao qual o interior se ajusta, o estranho tornando-se o familiar, a segunda transpõe o interior prestes a saltar para o exterior e caracteriza o mais familiar como algo de hostil. (p. 174)

Reduzir a pluralidade à dimensão do Eu mesmo é "fúria de destruição". Destruição da palavra, de rostos, de fotos.

\section{Palavras}

Na fita, este é o quadro de abertura. O jovem monge cristão, Kiril, protege Samira, uma jovem albanesa muçulmana que foge de uma gangue liderada por Mitre, macedônio cristão. Seu grupo vai procurá-la no mosteiro de cristãos ortodoxos e não a encontrando permanece do lado de fora da capela, aguardando. Quando Samira e Kiril procuram fugir vão em direção à família de Samira que quer forçá-la a permanecer em casa, como muçulmana, e abandonar Kiril, cristão. Ela vai ao encontro de Kiril e é assassinada por seu irmão. Desfazem-se os laços do amor, proteção, solidariedade e confiança, vínculos que definiam a esfera privada da família, e também o espaço público. Com efeito, em pesquisa do Centro de Pesquisa e Documentação do Rio de Janeiro (CPDOC), verificou-se o desaparecimento de um dos traços mais essenciais da tradição democrática ocidental: a comunidade política. Assim como declina a percepção de direitos sociais, civis e políticos, o mesmo ocorre com a cidadania entendida como confiança nos concidadãos. Na fita, a desconfiança se agravou, pois se insere no coração das próprias famílias, o irmão 
assassinando a irmã, o primo assassinando o primo. A desconfiança e o ódio, antes a salvo nas relações de parentesco ou de amizade, destituem o laço afetivo de pessoas que antes se relacionavam como comunidade política, à distância do poder ou do desejo de dominação. Como escreveu La Boétie no século XVI, a amizade é essa relação entre homens livres e iguais, tecida no bem-querer e no bem-fazer, em que os amigos suprem reciprocamente as limitações uns dos outros e formam uma companhia de homens livres que imita a autossuficiência do divino e diminui os efeitos dramáticos da condição humana de seres expostos, vulneráveis e mortais. Até mesmo os vínculos da vida privada encontram-se em extinção.

Em sua abertura, o filme confronta duas formas de silêncio: o da contemplação e o da opressão. De início o voto de silêncio tem o sentido de preparar o monge para o "mais elevado", o sublime, o divino. O fervor religioso e a reclusão preparam a palavra e a comunicação entre os homens através do divino, o silêncio é um gesto para o Absoluto. Confiscada a palavra pela violência e pelo terror, quando não há mais normas de convivência tradicionais nem lei que se exerça, instala-se o silêncio da opressão. Assim, quando Alexander procura proteger Samira, a adolescente acusada pelo grupo de Mitre de assassinato, ele diz ao primo que não use a vingança, que a justiça resolva o conflito, pois para prendê-la há a polícia e para julgá-la a lei, ele é silenciado e morto por seu primo. Também Samira, na sequência, será morta pelo próprio irmão. Nesta perspectiva, o mundo contemporâneo, ruidoso e tagarela, não é o da palavra comunicativa - da barreira contra a violência -, mas o do silêncio da opressão. Por isso Karl Kraus escreveu: "se hoje alguém tiver algo a dizer, que dê um passo adiante, tome a palavra e se cale". Costuma-se creditar à palavra a origem da democracia e Hannah Arendt considera, antes disso, o episódio inaugural da Ilíada, quando Agamêmnon acusa Aquiles de covardia. Na honra heroica, a uma ofensa recebida, o herói deveria responder pelo assassinato. Porém, Homero relata: "palavras atravessaram a barreira de seus dentes". A palavra, para Hannah Arendt, encontra-se, pois, não só na origem da democracia, mas da própria civilização. Na fita, do silêncio da contemplação passa-se ao da opressão.

De início não sabemos quem é o fugitivo de cabelos de corte negligente e crescendo em desalinho; logo descobrimos tratar-se de uma adolescente vestida com um abrigo Adidas dos anos 1970. Algo impede o jovem padre de denunciá-la. Seus olhos são ligeiramente oblíquos e o negro das pupilas inunda a tela inteira. Na verdade, ambos vivem a mesma história, por isso Mancheviski os coloca em um espaço comum: a da guerra fratricida, compreendendo, à luz do pensamento grego, toda guerra como guerra civil porque todos pertencemos a uma mesma humanidade, o outro é uma das dimensões e possibilidades do $\mathrm{Eu}$ e do humano; antes de ser grego ou troiano, somos homens. De onde procede então o direito de matar? Na fita, não se trata de um direito, mas de sua suspensão, que expõe o homem à sua condição de "vida nua", a integridade do corpo e da vida sem as garantias do direito e da lei. Nomos e logos, as regras ou convenções sociais que se extrovertiam em um logos, capaz de dizer o útil e o prejudicial, o justo e o injusto silenciam-se.

Faz parte do primeiro episódio - "Palavras" - o assassinato por uma rajada de metralhadora de um pequeno gatinho e que prenuncia o pior, é violência nua que se expressa tão mais aterradora quanto o animal é frágil e indefeso para preservar sua vida. Para designá-la, os gregos nos legaram duas palavras: zoé e bios. Zoéé a vida de todos os viventes do universo, as plantas, os animais, homens e deuses; bios é um modo de vida. Não havendo para os gregos separação entre vida e modo de vida, zoé é animal e animal procede, por sua vez, de anima, de alma, por isso todos os viventes do universo possuem psyché. Mas a violência da cena não se esclarece à luz do intelectualismo da etimologia, mas evoca outras questões, como o atestam as observações de Horkheimer e Adorno na Dialética do Iluminismo:

Na história europeia, a Ideia do homem exprime-se na maneira pela qual ele é distinguido do animal. A ausência da razão no animal prova a dignidade do homem. Essa oposição foi matraqueada com tanta insistência e unanimidade pelos predecessores do pensamento burguês, os antigos judeus, os estóicos e os Padres da Igreja e, depois, pela Idade Média afora e os tempos modernos adentro, que ela passou a pertencer ao patrimônio básico da antropologia ocidental. (Horkheimer \& Adorno, 1985, p. 229)

A partir da separação homem e animal, a racionalidade da ciência se vincula à ideia de progresso e superioridade com respeito ao animal e à Natureza. Por esta razão Giorgio Agamben escreve:

Devemos aprender a conhecer o homem como o que resulta da desconexão de dois elementos (o vivente e o logos) e examinar não o mistério metafísico de sua conjunção, mas o mistério prático (moral) e político de sua separação. Pois o que é o homem . . . uma vez que é o resultado de divisões e cesuras incessantes? Trabalhar sobre essas cisões, perguntar-se de que maneira o homem foi separado do não-homem, o animal do humano, é mais urgente do que marcar posição acerca das grandes questões sobre os pretensos direitos e valores humanos. (Aganbem, 2011, pp. 33-34)

E talvez a esfera mais luminosa das relações com o divino dependa, de alguma forma, "da esfera mais obscura que nos separa dos animais". Pois se experimentamos mais dor diante de um dano causado a um animal do que a um homem:

1 Cena semelhante já se encontra no filme Malatesta, em que um soldado fascista assassina um gato e em Cartas de Iwo Jima de Clint Eastwood, em que um oficial japonês fascista assassina um cão. 
É porque o animal está privado de testemunhá-lo segundo as regras humanas de estabelecimento do dano e, consequentemente, todo dano é como uma injustiça que faz dele uma vítima ipso facto. - Pois, se não há como testemunhar, não há sequer dano, ou pelo menos ele não pode ser estabelecido - Eis por que o animal é o paradigma da vítima. (Lyotard, 1983, p. 50)

O silêncio em um mundo que inviabiliza o silêncio é o de ruídos aterrorizadores das guerras e de sua opressão.

\section{Rostos}

Anne é editora em uma agência de fotografia, dividida entre o marido e o amante macedônio Alexsander, fotógrafo vencedor do Prêmio Pulitzer de fotorreportagem. Alexsander decide voltar para sua aldeia na Macedônia após dezesseis anos de ausência, lá deparando com crianças brincando com metralhadoras, civis armados e sua casa em ruínas, apenas a chave guardada no mesmo lugar; desfeitas agora todas as relações de afabilidade, parentesco e confiança, o lar não é mais um espaço seguro e acolhedor. O "acosmismo" é, no dizer de H. Arendt, o sentimento de ser estranho no mundo, é a perda do sensus communis, de um mundo comum, sentimento que Peter Szondi detectou no encontro, em Paris, dos foragidos do nazismo, quando alguns intelectuais judeus reunidos conversavam sobre os países para onde viajariam, Inglaterra, Suécia, Noruega, Estados Unidos, quando, por último, alguém iria para o Uruguai, a que, com admiração perguntou-se: "Por que tão longe?". A resposta foi: "Longe de onde?". Na perda de uma referência estável desaparece o próximo e o distante, resultando o sentimento de ser estranho no mundo. Simultaneamente à chegada de Alexsander na Macedônia e a seu assassinato, Anne se encontra com o marido em um restaurante de Londres e ele é morto em um ataque criminoso. Ela lhe diz ao mesmo tempo três coisas: que está grávida, que quer o divórcio e que o ama. Um confronto entre um "cliente" estrangeiro, provavelmente um macedônio, e um garçom talvez albanês termina com o agressor sendo expulso do restaurante, mas que retorna em seguida, atirando aleatoriamente contra todos no estabelecimento. Em "rostos", um boletim radiofônico fala de uma explosão de bombas na Oxford Street como uma premonição ou preparação para o massacre no Restaurante, assegurando que a audiência compreende que a violência está sempre por perto, mesmo em lugares pacíficos. Londres, no filme, não oferece as cores douradas da paisagem da Macedônia, o cinzento perpétuo de Londres chama a atenção para uma tranquilidade que é o contrário da paz, assim como a beleza da paisagem da Macedônia é a antítese do paraíso terrestre. Anne sobrevive e, entre os escombros, encontra seu marido morto com o rosto inteiramente desfigurado. $\mathrm{O}$ rosto possui dimensão metafísica pela significação espiritual e, nos traços que o caracterizam, revela-se sua "vulnerabilidade". A relação do Eu e do Outro faz dele o portador de uma vulnerabilidade, o rosto trazendo consigo a alteridade do outro e a subjetividade do sujeito:

O rosto, precisamente em sua nudez sem defesa, em vulnerabilidade absoluta, em seu ser estrangeiro a todo contexto, ao mundo mesmo, encontra-se no rastro do absolutamente ausente, ele é o ícone de um passado (passagem) irrecuperável. Por isso ele é imagem de Deus, por isso ele me é confiado de maneira irremissível. É em consequência desse abandono que surge minha responsabilidade. ... Como se vê, a ênfase é deslocada, aqui, para a perspectiva do outro: não se trata mais de perguntar "o que será de mim?", porque esta questão, minha subjetividade, torna-se possível pela invocação que o rosto me dirige, fazendo-me perguntar “o que será dele?". (Tarter, 2004, p. 215)

Se o rosto é o mais vulnerável do ser humano, que o revela frágil, exposto e mortal, olhar nos olhos do outro desfaz a possibilidade de matá-lo, pois seu olhar me excede e abre a ética como filosofia primeira. A experiência ética funda-se no movimento que nos leva em direção do outro, para a "alteridade e exterioridade do outro", para sua bondade, relação marcada pelo desinteresse no sentido de não se exigir do outro qualquer reciprocidade. É o encontro com o Outro, o face a face que me engaja na responsabilidade e na "fraternidade humana". O rosto expressa, simultaneamente, a fragilidade do outro e um mandamento: “ não matarás". A presença do Outro não opõe uma força à outra, como um dado objetivo que poderia ser calculado e controlado - pois a imprevisibilidade de sua reação, ou melhor, a transcendência de seu ser com respeito ao sistema de forças -, mas é resistência ética. É por um a mais do rosto, seu transbordamento em relação a mim o que desestabiliza relações abstratas e de poder entre os homens: anterior à guerra de todos contra todos, ao hobbesianismo que parece ter razão no mundo contemporâneo, é a dimensão ética do rosto de que decorre, para Lévinas, a impossibilidade de matar. Se a liberdade hobbesiana conduz ao choque, à colisão violenta, é por ser uma "liberdade sem rosto", a morte lhe é abstrata porque a vida também o é. As populações deslocadas por regimes políticos só possuem a vida derrisória das estatísticas. Lévinas refere-se às enormes massas humanas desterritorializadas que tinham sua maneira peculiar de conviver e de apertar as mãos, extinta no mundo moderno, em um século que faz questão de apresentar-se como o império da razão quando, em verdade, só procura as razões de amar que este século perdeu. Não se conhece mais a cor dos olhos daqueles a quem se mata.

Os fenômenos totalitários, assassinatos em massa ou a volatilização do Mal e da crueldade do crime, atestam a dimensão "política" da contemporaneidade. A perda do rosto, a incapacidade de olhar. Para Lévinas, a resistência ética ao mundo contemporâneo pertence à "epifania do rosto" e do olhar. Na contramão do hobbesianismo contemporâneo, a guerra não é, para Lévinas, a primeira forma do encontro entre os homens: se não o afirmarmos, 
logo estaremos em um mundo de revanche, de guerra, da afirmação prioritária de um grupo, religião, etnia, nacionalidade (Lévinas, 2000). No apogeu da civilização científica e da comunicação, os desenvolvimentos tecnológicos não desempenham uma função democratizante. Como escreveram Benjamin, Adorno, Horkheimer e Marcuse, o arcaico, a violência mítica e sacrificial, é ativamente produzida e preservada no coração da modernidade tecnológica. No apogeu da civilização iluminista, a barbárie é produzida e cultivada pela civilização. No ataque terrorista no restaurante o rosto fica desfigurado, desaparece o rosto.

\section{Imagens}

Alexsander chega a sua antiga aldeia na Macedônia e o primeiro a recepcioná-lo é Mitre. Anne tenta contatá-lo por telefone de Londres para transmitir o que havia ocorrido no restaurante sem o conseguir, a tecnologia moderna que prometeu aproximar os homens e colocá-los em comunidade e comunicação, é insuficiente para a comunicação em um mundo em ruínas. Com efeito, as línguas não comunicam mais os homens, é um mundo de Babel sem Pentecostes. Babel sem Pentecostes, os homens não se compreendem mais no interior de uma mesma língua.

Alexsander, na Macedônia, visita sua antiga paixão em um bairro albanês, onde só pode ingressar se um dos moradores, armado, o permitir, ela que vem a ser a mãe da jovem da primeira narrativa, Samira. Ela se chama Hanna, portanto a Anne de Londres é o duplo da Hanna albanesa, cada identidade se desdobra em outras, uma está na outra, por isso também o círculo não é redondo e o tempo não pára, o retorno ao início é o mesmo e é outro. Por ter ido visitá-la, é ameaçado tanto pelos muçulmanos quanto por seus parentes cristãos. E quando um dos primos de Alexsander é encontrado morto, os aldeões ortodoxos sequestram Samira. À noite Hanna visita Alexsander para que ele consiga libertar sua filha e, quando ele tenta proteger a jovem, é assassinado por seu primo. Simultaneamente Anne chega à Bósnia vinda de Londres e testemunha o assassinato. Samira foge de lá para o Mosteiro. Aqui então o sentido do grafite nos muros de Londres que acompanha toda a fita, "o círculo não é redondo", em um filme que trata do "círculo vicioso da violência". Na primeira parte, há uma aparição brevíssima de Anne chegando para testemunhar o assassinato de Alexsander; na segunda parte, "Rostos", Anne examina uma fotografia que prefigura o mesmo acontecimento. Mas na fita de Manchevski, se "o círculo não é redondo" é porque diz respeito àqueles que "tomam posição", deslocando o parti pris da violência, em um universo no qual a não-violência é criminalizada pelos que "tomam posição", isto é, aqueles que exercem a violência que se autoconcebe como legítima, que substitui a ineficácia da Lei e descrença em seu sentido e aplicabilidade. "Rostos" e "palavras" se referem a uma cultura de "transcendência" da violência o que significa não haver "eterno retorno do mesmo". O que significa a morte para a sociedade que a produz? Há no filme um profundo sentimento de responsabilidade - o fotógrafo que protege a jovem Samira pára de fotografar por se sentir responsável pelo assassinato que ele mesmo fotografou. Um soldado macedônio que se aproxima de Alexsander retira, arbitrariamente, de uma fila, um prisioneiro muçulmano e o executa para que o fotógrafo possa fotografar uma cena "de impacto". Assim, a questão das imagens no mundo contemporâneo é colocada no sentido de sua perversão quando utilizadas como espetáculos. Com efeito, o modo obsceno de difusão via satélite de corpos mutilados evoca "a urgência da elaboração de uma carta ética que enquadre a iconografia da informação na época de conflito armado" (Meddeb, 2004, p. 256). A fita indica a urgência de um acordo tácito de forma a não proliferarem imagens banalizadoras da violência de modo a só serem exibidas quando absolutamente necessárias à compreensão dos acontecimentos. A violência contemporânea, na época da técnica, revela a desresponsabilização do ato criminoso que, segundo Marcuse, Adorno, Horkheimer, deve-se à transferência do poder humano ao mecânico (as armas), do controle individual ao controle remoto.

Mas o tempo pode "voltar atrás" e tudo recomeçar de outra maneira. Há na fita, signos precursores, não há a sequência espaciotemporal, ou dialética hegeliano-marxista de tese, antítese e síntese. A narrativa é não linear, há enigmas não inteiramente resolvidos. $\mathrm{O}$ filme apresenta a possibilidade de trânsito entre as culturas e redenção pela arte, o que se reconhece principalmente na cena em que Alexsander, o fotógrafo, chega à Macedônia, anda de bicicleta assobiando a música "Raindrops keep falling on my head", a trilha sonora de Bonnie and Clyde. Há esperança, se a arte cumprir sua missão civilizatória, para utilizarmos uma expressão de Norbert Elias. O círculo não se fecha, mas vai se desenrolando, o círculo se rompe e o tempo se põe novamente em marcha. Os tempos não se fecham pois se multiplicam, o início deve ser revisto com o fim, e, também, o fim é um outro recomeço que não é repetição e eterno retorno do mesmo, da violência e do terror. A história como sucessão de fatos não é fixa, nem linear e contínua: pode mudar também no passado. $O$ futuro desce ao interior do passado para redimi-lo, deslocá-lo, modificá-lo. A história não é previsível nem repetição contínua, o tempo move-se em todas as direções, como o espaço (Canevacci, 1996). Se o tempo não pára e o círculo não se fecha, aí reside a esperança, pois o fechamento do círculo e a imobilidade do tempo seriam desesperadores. Diferentemente da história das grandes narrativas, negociadora de tratados e armistícios, a imaginação estética desmente a História que entende a política como a continuação da guerra por outros meios, como oposição entre amigos e inimigos. Desordenando as cronologias, em Antes da Chuva ainda ninguém matou e ninguém foi morto, nem a jovem albanesa, nem Nick, o marido de Anne, tampouco Aleksander. Por isso, a arte permite reabrir o tempo que não é um círculo que se fecha; há sempre muitas possibilidades de

2 Massimo Canevacci discute esse assunto em seu livro Sincretismo: uma exploração das hibridações culturais. 
viver e resolver conflitos. Porque a fita expõe as violências e massacres - os do passado nos afrescos do templo do mosteiro, os do presente nas guerras do presente, a arte e a religiosidade significam a utopia do possível. Neste sentido, Benjamin (1978) escreveu:

Sobre nosso planeta muitíssimas civilizações andaram sobre ruínas, no sangue e no horror. Como é natural, é necessário o anseio de experimentar uma civilização que tenha deixado para trás tanto o sangue quanto o horror. E assim estou inclinado a conceber ... que nosso planeta não faça outra coisa senão esperar tal civilização. (p. 698)

Esse momento epifânico em que advirá a paz sem nenhuma violência é um acontecimento no limiar do tempo, ele é "messiânico": "para instaurar o reino da paz", escreve Bloch (1985),

não é necessário destruir tudo e dar início a um mundo completamente novo, basta afastar um pouco esta xícara ou este arbusto ou esta pedra, e assim todas as coisas. Mas esse pouquinho é tão difícil de realizar e tão difícil é encontrar sua medida que, no que concerne ao mundo, os homens não o fazem e é necessário que chegue o Messias. (pp. 201-202)

Esse momento messiânico, na fita, é esse tempo do "antes"; "antes" da chuva significando o momento em que ainda nada aconteceu e depois do qual tudo estará perdido, pois cada acontecimento é sempre o primeiro e o último na álgebra do tempo.

\section{Before the rain: circle metamorphoses}

Abstract: This essay shows how the technological modernity continues to produce archaic behavior, preserved inside a civilization that intends to be logical and scientific. From school pseudoformation to political particularism, from the end of the public space to the legislation subjected to lobbying, we passed from the idea of polis - the city as common fate of a community that shares the same values - to the idea of thyase - groups organized as religious or political sects. The mode of production of the malaise and the violence in today's world is thus shown. It is argued that they can only be overcome by breaking up with the resentful particularism and with the policy that opposes friends and enemies. In this sense, the future and the past are equally contingent. The latter can be reopened in its unfulfilled hopes of peace and happiness and may lead us to reopen the present.

Keywords: fundamentalisms, technology, violence, enemy, parti pris, non-violence, identity, time acceleration, look.

\section{Avant la pluie: les métamorphoses du cercle}

Résumé: Cet essai vise à montrer comment la modernité technologique produit en permanence des comportements archaïques, préservés dans l'intérieur de la civilisation qui se prétend logique et scientifique. De la pseudoformation scolaire aux particularismes politiques, de la fin de l'espace public aux législations soumises aux lobbies, on passe de l'idée de polis - la ville comme destin commun d'une collectivité qui partage les mêmes valeurs - à l'idée de thyase - organisation de groupes sous la forme de sectes religieuses ou politiques. On montre, ainsi, le mode de production du malaise et de la violence dans le monde contemporain, ceux-ci ne pouvant être surmontés qu'en rompant avec les particularismes du ressentiment ainsi qu'avec la politique qui oppose ami et ennemi. En ce sens, tout comme le futur est contingent, le passé l'est aussi, pouvant être réouvert dans ses espoirs de paix et de bonheur non accomplis et qui peuvent faire advenir le présent.

Mots-clés: fondamentalismes, technologie, violence, ennemi, parti pris, non-violence, identités, accélération du temps, regarder.

\section{Antes de la lluvia: metamorfosis círculo}

Resumen: Este ensayo busca mostrar de qué manera la modernidad tecnológica produce en permanencia comportamientos arcaicos, preservados en el interior de la civilización que se pretende lógica y científica. De la pseudoformación escolar a los particularismos políticos, del fin del espacio público a las legislaciones sometidas a lobbies, se pasa de la idea de polis - la ciudad como destino común de una colectividad que divide los mismos valores - a la thyase - organización de grupos en la forma de sectas - religiosas o políticas. Se muestra, así, el modo de producción del malestar y de la violencia en el mundo contemporáneo, sólo pudiendo ser superados, rompiéndose con los particularismos resentidos y con la política que opone amigo y enemigo. En este sentido, así como el futuro es contingente, el pasado también lo es, pudiendo ser reabierto en sus esperanzas de paz y felicidad no cumplidas y que pueden reabrir el presente.

Palabras clave: fundamentalismos, tecnología, violencia, enemigo, parti pris, no-violencia, identidades, aceleración del tiempo, mirar. 


\section{Referências}

Agamben, G. (2011). O aberto: O homem e o animal. Lisboa, Portugal: Edições 70.

Agamben, G. (2002). Homo sacer: poder soberano e a vida nua. Belo Horizonte, MG: UFMG.

Angelot, M. (1998). Du ressentiment. Revue Autrement, 111112.

Arendt, H. (1979). Entre o passado e o futuro (M. W. B de Almeida, trad). São Paulo, SP: Perspectiva.

Benjamin, W. (1978). Briefe II: Herausgegeben und mit Anmerkungen versehen von Gershorn Scholem und Theodor W. Adorno. Frankfurt am Main: Suhrkamp.

Benjamin, W. (2006). Passagens (C. Mourão, \& I. Aron, trads.). Belo Horizonte, MG: UFMG.

Berardi, F. (1994). Mutazione e cyberpunk. Gênova, Itália: Costa \& Nolan.

Bloch, E. (1985). Spuren. Frankfurt am Main, Alemanha: Suhrkamp.

Canevacci. M. (1996). Sincretismo: Uma exploração da hibridação cultural. São Paulo, SP: Studio Nobel.

Desanti. (1956). Introduction à l'histoire de la Philosophie. Paris, França: Minuit.
Homero. (2003). Ilíada (Vol. 1, H. de Campos). São Paulo, SP: ARX.

Lévinas, E. (2000). Totalidade e infinito. Lisboa, Portugal: Edições 70.

Lyotard, J.-F. (1983). Le différend. Paris, França: Minuit.

Marcuse, H. (1982). Ideologia da sociedade industrial (G. Rebuá, trad.). Rio de Janeiro, RJ: Zahar.

Horkheimer, M., \& Adorno, T. W. (1985). Dialética do esclarecimento (G. de Almeida, trad.). Rio de Janeiro, RJ: Jorge Zahar.

Kepel, G. (2003). La revanche de Dieu. Paris, França: Seuil. Meddeb, A. (2004). O que esperar de uma guerra? In Civilização e barbárie. São Paulo, SP: Cia das Letras.

Szondi, P. (1991). Poésie et poétique de l'idéalisme allemand (J. Bollcak, trad.). Paris, França: Gallimard.

Tarter, S. (2004). Evento e ospitalità: Levianas, Derrida e la questione "straniera". Assis, Itália: Cittadella.

Recebido: 31/03/2015

Aceito: 20/05/2015 